\title{
STEM CELLS: NEW HOPE FOR SPINAL CORD INJURY
}

\author{
Marina Gazdic ${ }^{1}$, Vladislav Volarevic ${ }^{1}$ and Miodrag Stojkovic ${ }^{1,2}$ \\ ${ }^{1}$ Center for Molecular Medicine and Stem Cell Research, Faculty of Medical Sciences, University of Kragujevac, Serbia;; \\ ${ }^{2}$ Spebo Medical, Leskovac, Serbia
}

\section{MATIČNE ĆELIJE: NOVA NADA ZA POVREDE KIČMENE MOŽDINE}

\author{
Marina Gazdić ${ }^{1}$ Vladislav Volarević1 i Miodrag Stojković1,2 \\ ${ }^{1}$ Centar za molekulsku medicinu i izučavanje matičnih ćelija, Fakultet medicinskih nauka, Univerzitet u Kragujevcu, Srbija; \\ Spebo Medical, Leskovac, Srbija
}

\begin{abstract}
Stem cell therapy offers several attractive strategies for spinal cord repair. The regenerative potential of pluripotent stem cells was confirmed in an animal model of Spinal Cord Injury (SCI); nevertheless, optimized growth and differentiation protocols along with reliable safety assays should be established prior to the clinical application of hESCs and iPSCs. The therapeutic effects of mesenchymal stem cells (MSCS) in SCI result from neurotrophin secretion, angiogenesis, and antiinflammatory actions. Several preclinical SCI studies have reported that the occurrence of axonal extension, remyelination and neuroprotection occur after the transplantation of olfactory ensheathing cells (OECs). The transplantation of neural stem cells NSCs (NSCs) promotes partial functional improvement after SCI because of their potential to differentiate into neurons, oligodendrocytes, and astrocytes. The ideal source of stem cells for safe and efficient cell-based therapy for SCI remains a challenging issue that requires further investigation.
\end{abstract}

\section{SAŽETAK}

Terapija matičnim ćelijama pruža nekoliko atraktivnih mogućnosti za lečenje povreda kičmene moždine. Regenerativni potencijal pluripotentnih matičnih ćelija je potvrdjen $u$ animalnim modelima povrede kičmene moždine, medjutim, protokoli za kultivaciju i diferencijaciju ovih ćelija kao i testovi za potvrdu njihove bezbednosti tek moraju biti ustanovljeni kako bi se hESCs i iPSCs primenile u kliničkoj praksi. Terapijski efekat MSCs u povredi kičmene moźdine se zasniva na sposobnosti ovih ćelija da sekretuju neurotrofne $i$ antiinflamatorne faktore, kao i da promovišu angiogenezu. U nekoliko predkliničkih studija su pokazani rast aksona, remijelinizacija $i$ neuroprotektivno delovanje OECs. Transplantacija NSCs doprinosi funkcionalnom oporavku nakon povrede kičmene moždine diferencijacijom NSCs u neurone, oligodendrocite $i$ astrocite. Otkrivanje idealnog izvora matičnih ćelija za efikasnu i bezbednu terapiju povrede kičmene moždine i još uvek je izazov i zahteva dalja istraživanja.

\section{INTRODUCTION}

Spinal cord injury (SCI) is a devastating condition with permanent lifelong consequences (1). Epidemiological data show that the incidence of traumatic SCI in the US ranges from 27 to 83 per million while in Europe it is approximately 10-30 new cases per million (1). SCI usually results in sudden and long-lasting locomotor and sensory neuron degeneration below the injury (2).

The pathophysiological processes that underlie SCI comprise the primary and secondary phases of injury. During the primary phase, because of the direct mechanical trauma of the spinal cord by fractured and displaced bone fragments and disc material, there is massive axonal damage as well as neuronal and glial cell losses $(3,4,5)$. During the secondary phase of injury, further tissue damage occurs mostly from ischemia, electrolyte imbalance, inflammatory response, oxidative stress and excitotoxicity (3). Despite
๑

major advances in the medical and surgical care of SCI patients, there are currently no effective therapies for the treatment of traumatic SCI in humans (2). Stem cell therapy offers several attractive strategies for spinal cord repair. Stem cells may play an important role in the replacement of damaged neuronal and glial cells, axonal regeneration and remyelination, the restoration of neuronal circuitry, and the production of neurotrophic factors, anti-inflammatory cytokines, and other molecules that promote tissue repair and neovascularization.

In this review, we will evaluate the therapeutic role of human embryonic stem cells (hESCs), induced pluripotent stem cells (iPSCs), mesenchymal stem cells (MSCs), neural stem cells (NSCs), and olfactory ensheathing cells (OECs) for treating SCI, and we will cover some of the clinical trials that aim to translate laboratory stem cell research into clinical practice. 
Table 1. Therapeutic potential of stem cells for treatment of spinal cord injury

\begin{tabular}{|l|l|l|}
\hline Stem cell source & Advantages & Disadvantages \\
\hline hESCs & $\begin{array}{l}\text { differentiation into neurons and glia, } \\
\text { modulation of local immune response, } \\
\text { activation of endogenous neurogenesis. }\end{array}$ & $\begin{array}{l}\text { ethical issues, } \\
\text { immune rejection, } \\
\text { potential for tumor formation. }\end{array}$ \\
\hline iPSCs & differentiation into neurons, glia, and neural progenitor cells. & potential for tumor formation. \\
\hline MSCs & $\begin{array}{l}\text { providing trophic support to damaged neurons by } \\
\text { secreting angiogenic and neurotrophic factors, } \\
\text { modulation of local immune response. }\end{array}$ & $\begin{array}{l}\text { no universal consistency in cell sourcing, and } \\
\text { the optimal administration method. }\end{array}$ \\
\hline NSCs & differentiation into oligodendrocytes and astrocytes. & immune rejection, formation of glial scars. \\
\hline
\end{tabular}

hESCs, human embryonic stem cells; iPSCs, induced pluripotent stem cells; MSCs, mesenchymal stem cells; NSCs, neural stem cells.

\section{Human Embryonic Stem Cells}

hESCs are derived from the inner cell mass of human blastocysts; they have the ability to proliferate by maintaining both their pluripotency and their ability to differentiate into nearly all cell types, including neuronal and glial cells (6). Improved protocols have been developed to differentiate hESCs into motoneuron progenitors (MPs) and oligodendrocyte progenitors (OPCs) $(7,8)$. The transplantation of hESC-derived MPs and OPCs can efficiently recover locomotor function in both contusion and transection animal models of SCI $(7,8)$. The regenerative mechanism of hESC therapy for SCI depends on the potential of hESCderived OPCs and MPs to differentiate into neuronal and glial cells and the immunomodulatory characteristics of transplanted hESC-derived OPCs $(7,1)$.

Based on promising preclinical data from hESC-derived OPC transplants in rodent SCI models, the Food and Drug Administration (FDA) approved the first hESC clinical trial in 2009. The Geron Company attempted to test the safety of hESC-derived OPCs in human SCIs. Two million hESCderived OPC cells (GRNOPC1) within the acute phase were

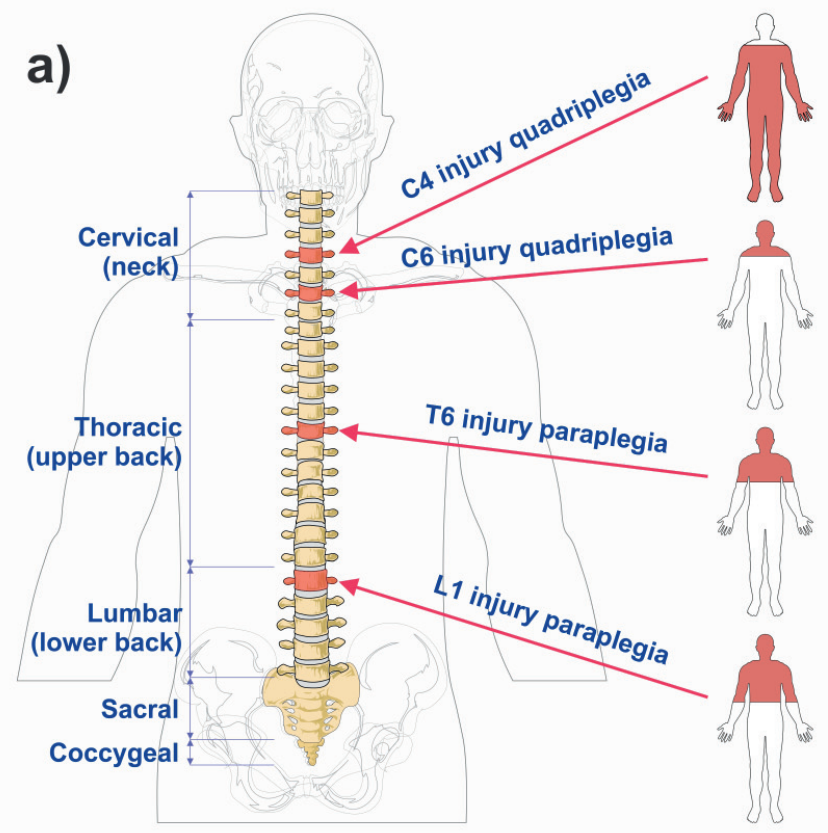

transplanted directly into the spinal cord of four ASIA A patients with complete thoracic SCI. In 2011, Geron discontinued this trial for financial reasons. The preliminary results indicated that GRNOPC1s do not cause any harm, but the debate about the efficacy of these cells still continues.

Concerns about the transplantation of hESC-derived neural cells to treating SCI are related to the ethical issues of cell derivation, the immune rejection of transplanted cells, the use of differentiation protocols that still involve mediums, growth factors, and supplements of animal origin, and the possibility of teratoma formation from incomplete or aberrant differentiation resulting in the formation of non-neural cells $(6,9)$.

\section{Induced Pluripotent Stem Cells}

iPSCs were originally generated by the ectopic expression of four transcription factors called, namely Oct4, Sox2, Klf4, and c-Myc in fibroblast cells by Takahashi and Yamanaka in 2006 (10). iPSCs show morphological, transcriptional, epigenetic, and phenotypic similarity to hESCs and can differentiate towards any cell in the human body including neurons, glia, neural progenitor cells (NPCs), and motoneurons (11).

Figure 1: Spinal cord injury: a) clinical signs and b) site of injury

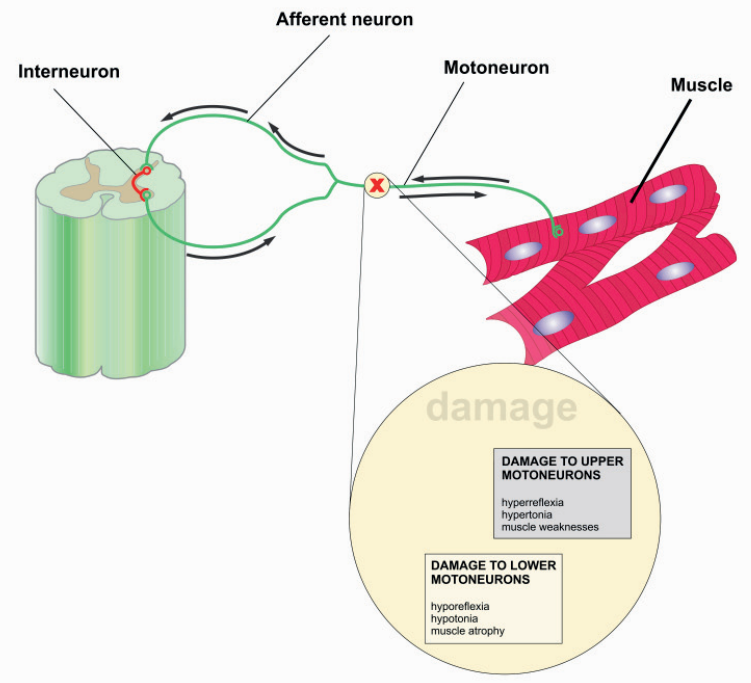

b) 


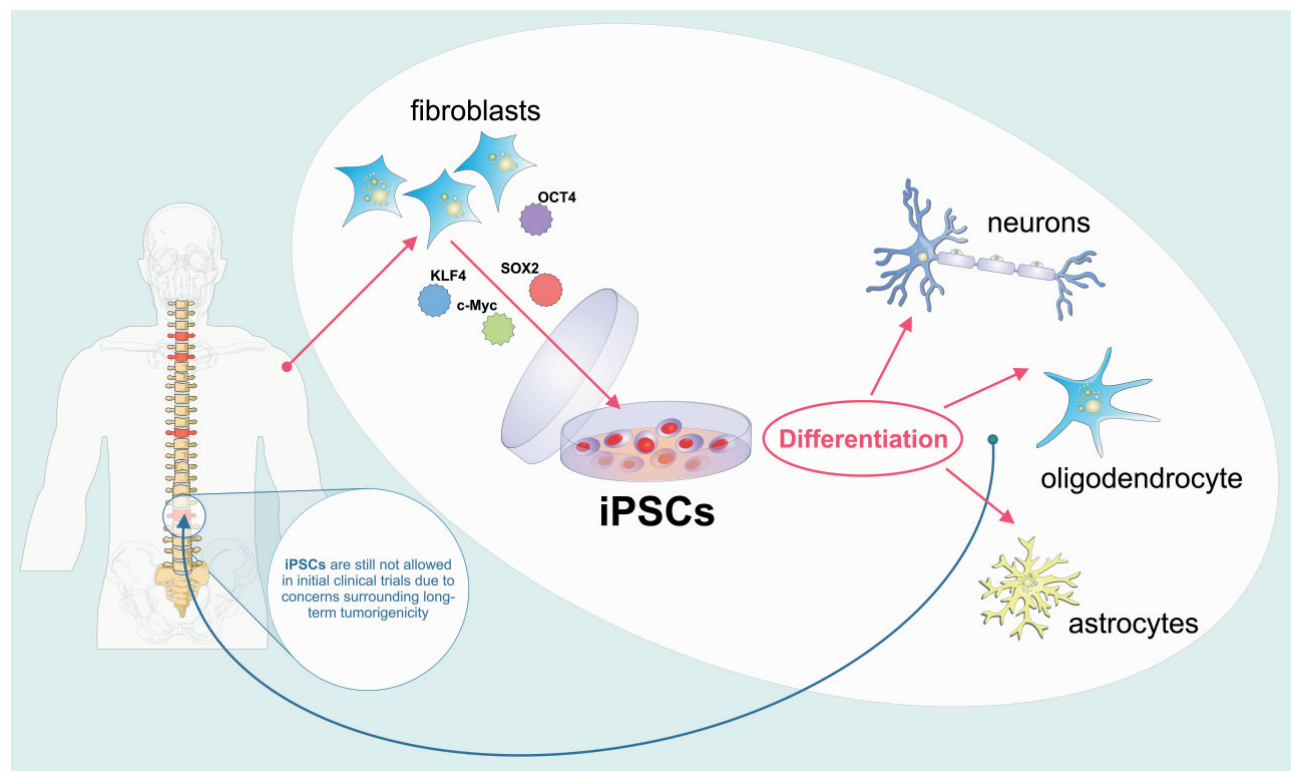

Figure 2: Method for derivation of iPSCs from adult somatic cell by introducing OCT4, SOX2, KLF4 and c-Myc. iPSCs can differentiate toward neurons, oligodendrocytes and astrocytes.

Patient-specific iPSCs derived from somatic cells through the ectopic expression of a defined set of factors do not present ethical and immnunological concerns (11). The primary concern about the use of these cells in clinical trials was with the reprogramming technology that involved viral vectors and their tumourigenicity (2). Some of the reprogramming issues are solved by the deriving iPSCs bythrough nonviral methods such as mRNA or chemicals and small molecules $(12,13)$. The regenerative potential of iPSCs was confirmed in a rodent model of SCI $(14,15)$; nevertheless, optimized growth and differentiation protocols and reliable safety assays should be established prior to the clinical application of iPSCs.

\section{Mesenchymal Stem Cells}

MSCs are adult, self-renewable, multipotent cells that can be found in almost all postnatal tissues (16). In addition to their stem/progenitor properties, MSCs have been shown to possess broad immunomodulatory abilities (16). The therapeutic effects of MSCs in SCI result from neurotrophin secretion, angiogenesis, and antiinflammatory actions, rather than direct translineage conversion to functional oligodendrocytes or neurons $(17,18,19,20,21)$. Engrafted MSCs act as neuroprotectors by secreting brain-derived neurotrophic factor (BDNF), glia cell line-derived neurotrophic factor (GDNF),

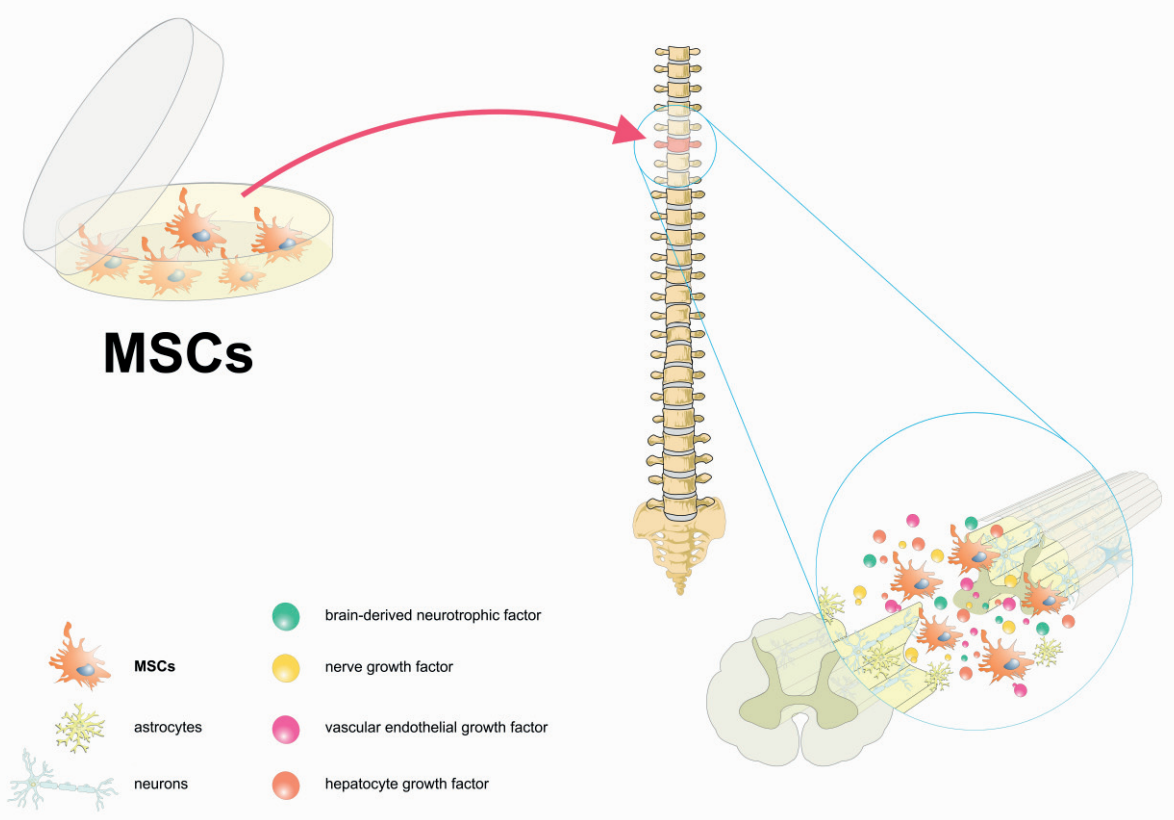

Figure 3: Transplanted MSCs act as neuroprotectors in spinal cord injuries by producing growth factors and anti-inflammatory cytokines. 
nerve growth factor (NGF), vascular endothelial growth factor (VEGF), and hepatocyte growth factor (HGF) $(22,23)$.

The number of clinical trials that employ MSCs for SCI treatment is increasing, indicating that despite several questions that still need to be addressed at pre-clinical levels, MSCs are considered potentially beneficial for translational studies (24). The pathological processes that occur at the lesion site in SCIs evolve over time, from the acute to subacute to chronic phases; therefore, transplantation at different times post-lesion may have varied effects (25). Sykova et al. suggested that performing MSC transplantation within a therapeutic window of 3-4 weeks following SCI is critical for the success of MSCbased therapy (26). Yoon et al. studied the effects of autologous bone marrow MSC transplantation in combination with the administration of granulocyte-macrophage colony-stimulating factor to 35 patients with complete SCIs at acute, subacute and chronic stages (27). No serious complications were reported, and $30.4 \%$ of patients who received MSCs at acute and subacute stages showed significant improvements in their ASIA scale position (27). Few clinical studies have shown neurological improvements in MSC-treated patients who during the chronic stage of SCI, when the glial scar is already present $(28,29,30$, 31,32 ). In these studies, MSCs were transplanted directly into the lesion intrathecally, intravenously and intrathecally (simultaneously) at once, and intraarterially.

Although the clinical study results are promising, there are important issues that should be addressed to achieve successful MSC-based therapy, that is, the universal consistency in cell sourcing and culture conditions, the ideal cell quantity and the optimal administration method $(24,1)$.

\section{Olfactory Ensheathing Cells}

OECs are a unique population of macroglia found in the lamina propria of olfactory mucosa, around the olfactory nerve fascicles and in the two outer layers of the olfactory bulb. OECs have the dual nature of astroglial cells and Schwann cells (33). Several preclinical SCI studies have re- ported the occurrence of axonal extension, remyelination and neuroprotection after OEC transplantation $(34,35,36$, $37,38)$. OECs migrate to injured sites and secrete a large number of factors that are necessary for the growth, development, differentiation, and maturation of different types of neurons and reduce astrocyte activity and glial scar formation $(39,40)$. Spinal cord regeneration and functional recovery depend on the nature and source of OECs, the injury model, the graft cell preparation, the time of transplantation, and the transplantation procedures (25).

Feron et al. performed a single-blind phase I clinical trial in which three patients with SCI (chronic injuries) received autologous OECs. The feasibility of the procedure and the safety of these cells were reported, but there was no evidence of clinical efficacy $(41,42)$. Lima et al. reported that the transplantation of minced olfactory mucosa in patients with chronic SCI was not significantly efficient (44). By contrast, recent clinical studies suggested that there was a neurological improvement in SCI patients after OEC transplantation $(44,45)$.

\section{Neural Stem Cells}

NSCs are multipotent cells with the potential to differentiate into neurons, oligodendrocytes, and astrocytes, and they can be efficiently propagated in vitro (46).

NSCs can be found in the periventricular subependymal layer, in the subgranular zone of the dentate gyrus, and in the ependymal regions lining the central canal (47). The activation of resident ependymal stem cells following SCI is not sufficient to promote recovery because the cells differentiate mostly into actrocytes and oligodendrocytes (48, 49). Several preclinical studies confirmed that the transplantation of NSCs promotes a partial functional improvement after SCI $(50,51)$. The transplantation of OPCs that had differentiated from ependymal stem cells efficiently recovered the locomotor function of an SCI animal model (47). The source of NSCs, the methods of cell isolation and preparation, the time of transplantation, the chosen
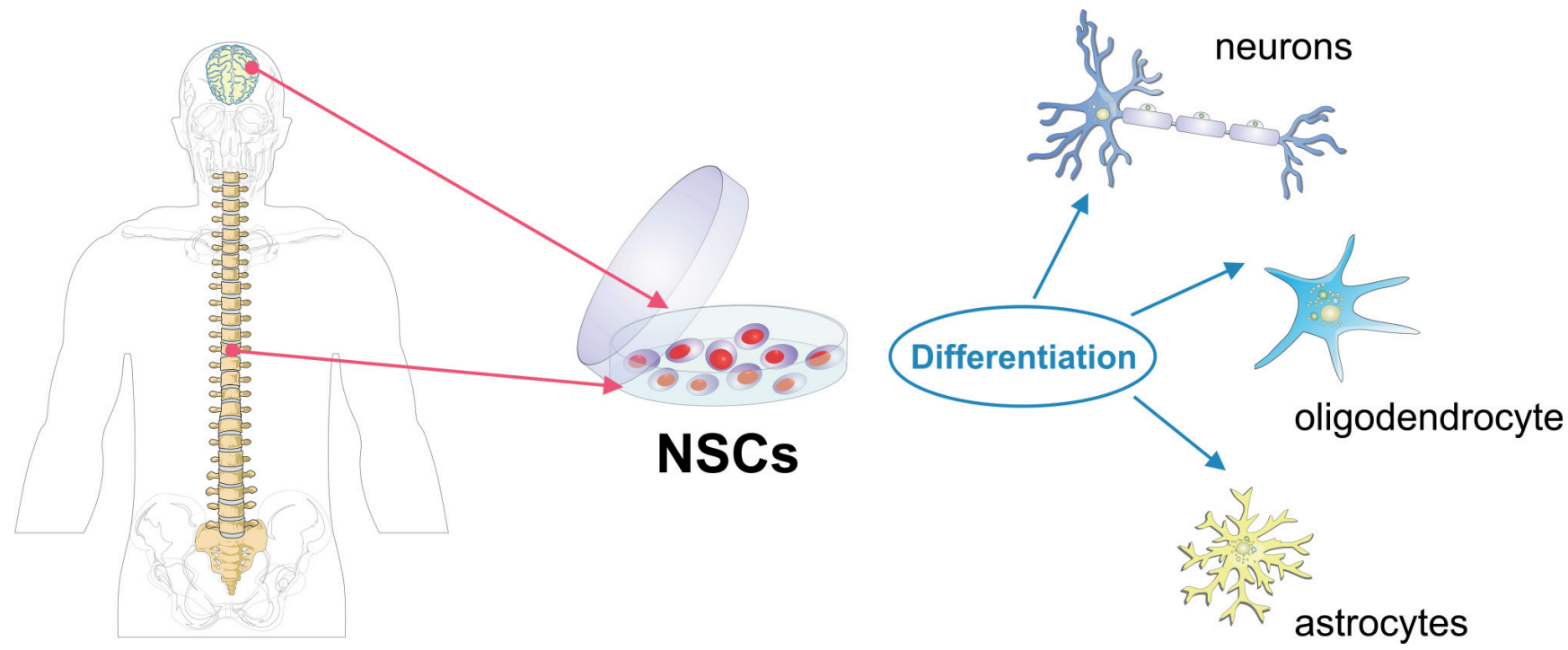

Figure 4: Potential uses of NSCs which were isolated from the adult brain and spinal cord as a source of neurons, oligodendrocytes, and astrocytes. 
immunosuppression, and the type of injury (contusion vs. transection) are important issues for achieving successful NSC-based therapy after SCI (49). Human NSCs have been isolated from foetal brains, and spinal cords have been isolated from aborted foetuses. Unlike adult NSCs, foetalderived NSCs generate neurons in addition to glia in the injured spinal cord (1).

Currently, two human trials involving allogeneic NSCs for SCI are ongoing. The primary objectives of these studies are to determine the long term safety and preliminary efficacy of NSC transplantation in subjects with thoracic spinal cord trauma.

\section{CONCLUSIONS}

Numerous preclinical studies suggest that stem cells are able to enhance recovery following SCI. However, the ideal source of stem cells for the efficient and safe cell-based therapy of SCI remains a challenging issue that requires further investigation and continuous cooperation between clinicians, researchers, and patients.

\section{ACKNOWLEDGMENTS:}

This study was supported by the Serbian Ministry of Science (project numbers ON 175069 and ON175103). We highly appreciate and acknowledge the generous assistance of $\mathrm{Mr}$. Milan Milojevic, who contributed to the creation of the figures in this article. The authors declare no conflicts of interest.

\section{REFERENCES}

1. Volarevic V, Erceg S, Bhattacharya SS, Stojkovic P, Horner P, Stojkovic M. Stem Cell-Based Therapy for Spinal Cord Injury. Cell Transplantation 2013; 22(8):1309-23.

2. Lukovic D, Moreno Manzano V, Stojkovic M, Bhattacharya SS, Erceg S. Concise review: human pluripotent stem cells in the treatment of spinal cord injury. Stem Cells 2012; 30(9):1787-92.

3. Rowland JW, Hawryluk GW, Kwon B, Fehlings MG. Current status of acute spinal cord injury pathophysiology and emerging therapies: Promise on the horizon. Neurosurg. Focus 2008; 25:E2.

4. McTigue DM, Tani M, Krivacic K et al. Selective chemokine mRNA accumulation in the rat spinal cord after contusion injury. J Neurosci Res 1998;53:368-376.

5. Grossman SD, Rosenberg LJ, Wrathall JR. Temporalspatial pattern of acute neuronal and glial loss after spinal cord contusion. Exp Neurol 2001;168:273-282.

6. Erceg S, Ronaghi M, Stojković M. Human embryonic stem cell differentiation toward regional specific neural precursors. Stem Cells 2009. 27(1):78-87.

7. Erceg S, Ronaghi M, Oria M, et al. Transplanted oligodendrocytes and motoneuron progenitors generated from human embryonic stem cells promote locomotor recovery after spinal cord transection. Stem Cells 2010; 28:1541-1549.

8. Nistor GI, Totoiu MO, Haque N, Carpenter MK, Keirstead HS. Human embryonic stem cells differentiate into oligodendrocytes in high purity and myelinate after spinal cord transplantation. Glia 2005; 49:385-396.

9. Mothe AJ, Tator $\mathrm{CH}$. Advances in stem ell therapy for spinal cord injury. J Clin Invest. 2012; 122(11):3824-34.

10. Takahashi K, Yamanaka S. Induction of pluripotent stem cells from mouse embryonic and adult fibroblast cultures by defined factors. Cell 2006; 126:663-676.

11. Lukovic D, Moreno-Manzano V, Klabusay M, Stojkovic M, Bhattacharya SS, Erceg S. Non-coding RNAs in pluripotency and neural differentiation of human pluripotent stem cells. Front Genet. 2014; 14;5:132.

12. Warren L, Manos PD, Ahfeldt T, et al. Highly efficient reprogramming to pluripotency and directed differentiation of human cells with synthetic modified mRNA. Cell Stem Cell 2010; 7:618-630.

13. Zhou H, Wu S, Joo JY, et al. Generation of induced pluripotent stem cells using recombinant proteins. Cell Stem cell 2009; 4:381-384.

14. Tsuji O, Miura K, Okada Y, et al. Therapeutic potential of appropriately evaluated safe-induced pluripotent stem cells for spinal cord injury. Proc Natl Acad Sci USA 2010; 107:12704-12709.

15. Nori S, Okada Y, Yasuda A, et al. Grafted human-induced pluripotent stem-cell-derived neurospheres promote motor functional recovery after spinal cord injury in mice. Proc Natl Acad Sci USA 2011;108: 16825-16830.

16. Volarevic V, Al-Qahtani A, Arsenijevic N, et al. Interleukin-1 receptor antagonist (IL-1Ra) and IL-1Ra producing mesenchymal stem cells as modulators of diabetogenesis. Autoimmunity 2010; 43: 255-63.

17. Hawryluk GW, Mothe AJ, Chamankhah M, Wang J, Tator C, Fehlings MG. In vitro characterization of trophic factor expression in neural precursor cells. Stem Cells Dev. 2012; 21(3):432-447.

18. Himes BT, Neuhuber B, Coleman C et al. Recovery of function following grafting of human bone marrowderived stromal cells into the injured spinal cord. Neurorehabil Neural Repair 2006; 20(2):278-296.

19. Hawryluk GW, Mothe A, Wang J, Wang S, Tator C, Fehlings MG. An in vivo characterization of trophic factor production following neural precursor cell or bone marrow stromal cell transplantation for spinal cord injury. Stem Cells Dev. 2012; 21(12):2222-2238.

20. Caplan AI, Dennis JE. Mesenchymal stem cells as trophic mediators. J Cell Biochem. 2006; 98(5):1076-1084.

21. Ruff CA, Wilcox JT, Fehlings MG. Cell-based transplantation strategies to promote plasticity following spinal cord injury. Exp. Neurol. 2012; 235:78-90.

22. Kim HJ, Lee HJ, Kim SH. Therapeutic effects of human mesenchymal stem cells on traumatic brain injury in rats: Secretion of neurotrophic factors and inhibition of apoptosis. J. Neurotrauma 2010; 27:131-138. 
23. Sasaki M, Radtke C, Tan AM, et al. BDNF hypersecreting human mesenchymal stem cells promote functional recovery, axonal sprouting, and protection of corticospinal neurons after spinal cord injury. J. Neurosci. 2009; 29:14932-14941.

24. Martinez AM, Goulart CO, Ramalho Bdos S, Oliveira JT, Almeida FM. Neurotrauma and mesenchymal stem cells treatment: From experimental studies to clinical trials. World J Stem Cells 2014; 6(2):179-94.

25. Li J, Lepski G. Cell transplantation for spinal cord injury: a systematic review. Biomed Res Int. 2013; 2013:786475.

26. Syková E, Homola A, Mazanec R, et al. Autologous bone marrow transplantation in patients with subacute and chronic spinal cord injury. Cell Transplant. 2006; 15:675-687.

27. Yoon SH, Shim YS, Park YH, et al. Complete spinal cord injury treatment using autologous bone marrow cell transplantation and bone marrow stimulation with granulocyte macrophage-colony stimulating factor: phase I/ II clinical trial. Stem Cells 2007; 25:2066-2073.

28. Chernykh ER, Stupak VV, Muradov GM, et al. Application of autologous bone marrow stem cells in the therapy of spinal cord injury patients. Bull. Exp. Biol. Med. 2007; 143:543-547.

29. Kumar A, Kumar S, Narayanan R, Arul K, Baskaran M. Autologous bone marrow derived mononuclear cell therapy for spinal cord injury: A phase I/II clinical safety and primary efficacy data. Exp. Clin. Transplant. 2009; 7:241- 248.

30. Callera F, do Nascimento RX. Delivery of autologous bone marrow precursor cells into the spinal cord via lumbar puncture technique in patients with spinal cord injury: A preliminary safety study. Exp. Hematol. 2006; 34:130-13.

31. Cristante AF, Barros-Filho TE, Tatsui N, et al. Stem cells in the treatment of chronic spinal cord injury: Evaluation of somatosensitive evoked potentials in 39 patients. Spinal Cord 2009; 47:733-738.

32. Deda H, Inci MC, Kürekçi AE, et al. Treatment of chronic spinal cord injured patients with autologous bone marrowderived hematopoietic stem cell transplantation: 1-year follow-up. Cytotherapy 2008; 10:565-574.

33. Rao YJ, Zhu WX, Du ZQ, et al. Effectiveness of olfactory ensheathing cell transplantation for treatment of spinal cord injury. Genet Mol Res. 2014; 13(2):4124-9.

34. García-Alias G, Lopez-Vales R, Fores J, Navarro X, Verdu E. Acute transplantation of olfactory ensheathing cells or Schwann cells promotes recovery after spinal cord injury in the rat. J. Neurosci. Res. 2004; 75:632-641.

35. Kubasak MD, Jindrich DL, Zhong H, et al. OEG implantation and step training enhance hindlimb-stepping ability in adult spinal transected rats. Brain 2008; 131:264-276.

36. Munoz-Quiles C, Santos-Benito FF, Llamusí MB, Ramon-Cueto A. Chronic spinal injury repair by olfactory bulb ensheathing glia and feasibility for autologous therapy. J. Neuropathol. Exp. Neurol. 2009; 68:1294-1308.
37. Radtke C, Sasaki M, Lankford KL, Vogt PM, Kocsis JD. Potential of olfactory ensheathing cells for cell-based therapy in spinal cord injury. J. Rehabil. Res. Dev. 2008; 45:141-151.

38. Ramon-Cueto A, Cordero MI, Santos-Benito FF, Avila J. Functional recovery of paraplegic rats and motor axon regeneration in their spinal cords by olfactory ensheathing glia. Neuron 2000; 25:425-435.

39. Woodhall E, West AK, Chuah MI. Cultured olfactory ensheathing cells express nerve growth factor, brainderived neurotrophic factor, glia cell line-derived neurotrophic factor and their receptors. Brain Res Mol Brain Res. 2001; 88(1-2):203-13.

40. Mayeur A, Duclos C, Honoré A, et al. Potential of olfactory ensheathing cells from different sources for spinal cord repair. PLoS One 2013; 8(4):e62860.

41. Feron F, Perry C, Cochrane J, et al. Autologous olfactory ensheathing cell transplantation in human spinal cord injury. Brain 2005; 128:2951-2960.

42. Mackay-Sim A, Feron F, Cochrane J, et al. Autologous olfactory ensheathing cell transplantation in human paraplegia: a 3-year clinical trial. Brain 2008; 131:2376-2386.

43. Lima C, Pratas-Vital J, Escada P, Hasse-Ferreira A, Capucho C, Peduzzi JD. Olfactory mucosa autografts in human spinal cord injury: A pilot clinical study. J. Spinal Cord Med 2006; 29:191-203.

44. Tabakow P, Jarmundowicz W, Czapiga B, et al. Transplantation of autologous olfactory ensheathing cells in complete human spinal cord injury. Cell Transplant. 2013; 22(9):1591-612.

45. Zheng Z, Liu G, Chen Y, Wei S. Olfactory ensheathing cell transplantation improves sympathetic skin responses in chronic spinal cord injury. Neural Regen Res. 2013; 8(30):2849-55.

46. Hsu YC, Lee DC, Chiu IM. Neural stem cells, neural progenitors, and neurotrophic factors. Cell Transplant. 2007; 16:133-150.

47. Moreno-Manzano V, Rodríguez-Jiménez, FJ, GarcíaRoselló M, et al. Activated spinal cord ependymal stem cells rescue neurological function. Stem Cells 2009; 27:733-743.

48. Barnabe'-Heider F, Frisen J. Stem cells for spinal cord repair. Cell Stem Cell 2008; 3:16-24.

49. Ronaghi M, Erceg S, Moreno-Manzano V, Stojkovic M. Challenges of stem cell therapy for spinal cord injury: human embryonic stem cells, endogenous neural stem cells, or induced pluripotent stem cells? Stem Cells 2010; 28(1):93-9.

50. Iwanami A, Kaneko S, Nakamura M, et al. Transplantation of human neural stem cells for spinal cord injury in primates. J. Neurosci. Res. 2005; 80:182-190.

51. Parr A. M, Kulbatski I, Zahir T, et al. (2008). Transplanted adult spinal cordderived neural stem/progenitor cells promote early functional recovery after rat spinal cord injury. Neuroscience 155:760-770. 